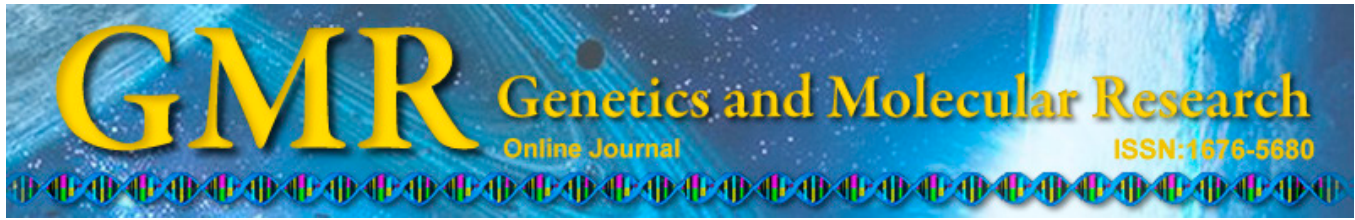

\title{
Dynamic changes of virus load in supernatant of primary CEK cell culture infected with different generations of avian infectious bronchitis virus strains Sczy3 as revealed by real-time reverse transcription-polymerase chain reaction
}

Z.J. Wei, F.Y. Wang, M.P. Guo, Z.Z. Duan, N.L. Zou, P. Liu, Q.G. Yan, X.T. Wen, S.J. Cao and Y. Huang

Key Laboratory of Animal Disease and Human Health of Sichuan Province, College of Veterinary Medicine, Sichuan Agricultural University, Ya'an, Sichuan, China

Corresponding author: Y. Huang

E-mail: hyong601@163.com

Genet. Mol. Res. 14 (2): 6340-6349 (2015)

Received August 26, 2014

Accepted January 19, 2015

Published June 11, 2015

DOI http://dx.doi.org/10.4238/2015.June.11.9

\begin{abstract}
Infectious bronchitis virus (IBV) can multiply effectively in chick embryo kidney (CEK) cells after adapting to the chick embryo. To investigate the dynamic changes in IBV load in the supernatant of primary CEK cells, we developed an SYBR Green I-based real-time polymerase chain reaction assay to quantify nucleic copy numbers of the IBV-Sczy3 strain. The 20, 54, and 87th generations of CEK-adapted IBV-Sczy 3 strains were used to infect CEK cells, and then nucleic copy numbers in the samples of supernatant collected at $12,24,36,48,60$, and $72 \mathrm{~h}$ were detected. The results showed that the rapid growth period of the virus load of all the 3 generations was approximately $12-36 \mathrm{~h}$ post-
\end{abstract}


infection; the peak of the virus load appeared at $36 \mathrm{~h}$ post-infection and then decreased gradually in the order of 20th $>54$ th $>87$ th for the 3 generations of CEK-adapted strains; the dynamic change curve of the IBV load in the supernatant of primary CEK cells showed a single peak. The results of this study provide a useful reference for CEK-adapted IBV field strains and the production of CEK-attenuated IBV vaccine.

Key words: Chick embryo kidney cells; Dynamic changes; Real-time reverse transcription-polymerase chain reaction; Infectious bronchitis virus

\section{INTRODUCTION}

Infectious bronchitis (IB) is a highly contagious respiratory disease that is hazardous to the poultry industry. The etiologic agent is infectious bronchitis virus (IBV), which replicates primarily in the respiratory tract and in some epithelial cells of the gut, kidney, and oviduct (Cavanagh and Naqi, 2003). Currently, dozens of serotypes and genotypes of IBV have been identified, and many more may be reported in the future, complicating the prevention and control of IB (De Wit et al., 1997). Currently, IB is mainly prevented by vaccination, and no specific medicine against this disease has been developed (Tan et al., 2009). IBV can propagate in a variety of host systems such as chicken embryos, chicken kidney cells (CK), chicken embryo kidney cells (CEK), and tracheal rings (Cofia and Peterson, 1971). Some studies have demonstrated that IBV strains can propagate in CEK cells only after adapting on chicken embryos. H120, Mass41, Conn46, and some field isolates have adapted to CEK cells, in which IBV can proliferate efficiently; the CEK-adapted strains can also be used for microneutralization tests (Gillette, 1973; Liu, 1983).

Real-time polymerase chain reaction (PCR) is a rapid, sensitive, and specific method used for nucleic acid detection and is widely used in the rapid detection of pathogens, quantification of nucleic acid copy numbers, and gene expression analysis (Bustin, 2002). For the quantification of IBV strains, determination of 50\% egg infectious dose or $50 \%$ tissue culture infectious dose can be used, but these methods are time-consuming and laborious. A fast and accurate detection method is critical for quantifying the dynamic change of virus load in the chick embryo or CEK cells infected with IBV.

IBV strains reportedly propagate in CEK cells after several passages on embryonated eggs; however, continuously passaging of IBV field strains on CEK cells 100 times has not been reported previously. To determine the proliferative pattern of different generations of CEK-adapted IBV strains in CEK cells, the QX-like IBV strain Sczy3, which has adapted to chicken embryos, was used to infect CEK cells, which were continuously passaged 100 times. Additionally, a SYBR Green I-based real-time PCR assay was established to monitor the dynamic changes in virus load in the supernatant of CEK cell cultures infected with different generations of CEK-adapted IBV Sczy3 strains. The cytopathic effect (CPE) was also observed. These results may provide useful reference for CEK-adapted IBV field strains and the production of a CEK-attenuated IBV vaccine. 


\section{MATERIAL AND METHODS}

\section{Viruses and passaging}

The IBV China/Sichuan/QX-like/Sczy3/200904 strain (referred to as Sczy3) was isolated from the kidneys of broilers presenting with dyspnea in April 2009; the chickens were obtained from a farm in Yaan City, Sichuan Province, China and the strain was passaged in eggs 5 times. The strain was shown to be a QX-like IBV based on genetic analysis (Zou et al., 2010). The stock virus was propagated in 9-11-day-old specific pathogen-free chicken embryos (Beijing Experimental Animal Center, Beijing, China), and the allantoic fluids were harvested $36 \mathrm{~h}$ post-inoculation and stored at $-70^{\circ} \mathrm{C}$.

CEK cells was prepared and cultured as previously described (Lukert, 1965, 1966). Briefly, primary CEK cells were prepared from the kidneys of 18-20-day-old specific pathogen-free chicken embryos, and maintained in Dulbecco's Modified Eagle Medium (Gibco, Grand Island, NY, USA) supplemented with 10\% fetal bovine serum (Tripathy, 1998). The allantoic fluid containing the IBV-Sczy3 strain was used to infect CEK cells at a confluency of $70-80 \%$ and the culture medium was replaced with Dulbecco's Modified Eagle Medium supplemented with 2\% fetal bovine serum. CEK cells were maintained at $37^{\circ} \mathrm{C}$ and $5 \% \mathrm{CO}_{2}$, and the supernatant was harvested $40 \mathrm{~h}$ post-inoculation and passaged. The characteristic CPE such as syncytia was also observed. The Sczy3 strain was passaged in CEK cells for 100 times, and the stock virus of each generation was stored at $-70^{\circ} \mathrm{C}$.

\section{Development of SYBR Green I-based real-time reverse transcription (RT)-PCR assay for IBV}

\section{Primer design}

Based on the cDNA sequences of the nucleocapsid gene of IBV-Sczy3 (GenBank Accession No. JF732903.1), primers IBVN1 and IBVN2 were designed to amplify the nucleocapsid gene (1246 bp) in the IBV genome and used for the construction of a standard plasmid. The other pair of primer pairs, IBVNR1 and IBVNR2, was designed and used for real-time PCR to amplify a 112-bp conserved segment of the nucleocapsid gene.

\section{RNA extraction and cDNA synthesis}

Genomic RNA was extracted from IBV-infected allantoic fluid using Trizol reagent (Takara Biotechnology, Dalian, China) according to manufacturer instructions and dissolved in $20 \mu \mathrm{L}$ sterile diethyl diethylpyrocarbonate-treated water and stored at $-70^{\circ} \mathrm{C}$ until further use. For the reverse transcription reaction, $10 \mu \mathrm{L}$ template RNA and $1 \mu \mathrm{L}$ random 6-mers $(10 \mu \mathrm{M})$ were added and mixed. The mixture was then heated to $65^{\circ} \mathrm{C}$ for $5 \mathrm{~min}$ and quickly cooled on ice for $5 \mathrm{~min}$. After brief centrifugation, $4 \mu \mathrm{L} 5 \mathrm{X}$ RT buffer, $2 \mu \mathrm{L} 2.5 \mathrm{mM}$ of each dNTP, $1 \mu \mathrm{L} 200 \mathrm{U} / \mu \mathrm{L}$ AMV reverse transcriptase, and $2 \mu \mathrm{L}$ RNasefree water were added. The reaction mixture was incubated at $37^{\circ} \mathrm{C}$ for $60 \mathrm{~min}$ and then at $70^{\circ} \mathrm{C}$ for $10 \mathrm{~min}$. 


\section{Construction of standard plasmids}

A 1246-bp long fragment of the NP gene of IBV Sczy3 strain was amplified using the primers IBVN1 and IBVN2 in a 50- $\mu \mathrm{L}$ reaction volume containing $25 \mu \mathrm{L} 2 \mathrm{X}$ Taq PCR MasterMix (Tiangen, Beijing, China), $2 \mu \mathrm{L} 10 \mu \mathrm{M}$ of each primer, $4 \mu \mathrm{L}$ cDNA, and $17 \mu \mathrm{L}$ RNasefree water. The optimum conditions for PCR were as follows: $94^{\circ} \mathrm{C}$ for $4 \mathrm{~min}, 10$ cycles at $94^{\circ} \mathrm{C}$ for $30 \mathrm{~s}, 55^{\circ} \mathrm{C}$ for $30 \mathrm{~s}, 72^{\circ} \mathrm{C}$ for $1 \mathrm{~min}$, and 20 cycles at $94^{\circ} \mathrm{C}$ for $30 \mathrm{~s}, 50^{\circ} \mathrm{C}$ for $30 \mathrm{~s}$, $72^{\circ} \mathrm{C}$ for $1 \mathrm{~min}$, and a final elongation at $72^{\circ} \mathrm{C}$ for $10 \mathrm{~min}$. The PCR product was analyzed on a $0.9 \%$ agarose in Tris-borate-EDTA buffer gel containing $0.5 \mathrm{mg} / \mathrm{mL}$ ethidium bromide.

PCR products corresponding to the predicted size of the target gene were isolated from agarose gels and purified using the E.Z.N.A. ${ }^{\mathrm{TM}}$ Gel Extraction Kit (Omega Bio-Tek, Norcross, GA, USA). Purified PCR products were ligated into a TA cloning vector pMD19-T (Takara) and transformed into DH5 a Escherichia coli competent cells. Confirmation of clones containing recombinant plasmid was achieved by PCR and restriction enzyme digestion. The recombinant plasmid was sequenced by Shanghai Sangon Biological Engineering Technology \& Services Co., Ltd. (Shanghai, China). The recombinant plasmid was named pMT-N and used as the DNA standard. The concentration of plasmid pMT-N was determined using a spectrophotometer (NanoDrop, Wilmington, DE, USA). DNA plasmid concentrations (C) were measured as the absorbance at $260 \mathrm{~nm}$, expressed in $\mathrm{g} / \mu \mathrm{L}$ and converted to copy numbers (N) per $\mu \mathrm{L}$ target DNA using the following equation:

$$
\left.\mathrm{N}=\left(\mathrm{C} \times 6.02 \times 10^{23}\right) / \text { plasmid MW (molecular weight }\right)
$$

(Equation 1)

\section{Standard curves and real-time PCR conditions}

To study the dynamic change in IBV load in the supernatant of CEK cells post-infection, each real-time RT-PCR assay was run along with a dilution series of the standard plasmid, which was used for calibration. A control containing no template was also included with each run. All real-time RT-PCR runs were conducted in a LightCycler instrument (IQ5; BioRad, Hercules, CA, USA) using the Real Master Mix (SYBR Green) Kit (Tiangen). First, 12.5 $\mu \mathrm{L} 20 \mathrm{X}$ SYBR solution was added to $1.0 \mathrm{~mL}$ 2.5X Real Master Mix and mixed completely, and then real-time PCR was carried out in a total volume of $20 \mu \mathrm{L}$ containing $9 \mu \mathrm{L}$ solution from the above reaction, $0.5 \mu \mathrm{L}$ each $20 \mu \mathrm{M}$ primer, $1 \mu \mathrm{L}$ cDNA, and $9 \mu \mathrm{L}$ PCR-grade water. The optimum thermal cycling parameters varied according to the gene being detected. Briefly, the optimum conditions for real-time PCR were as follows: $95^{\circ} \mathrm{C}$ for $5 \mathrm{~min}$, and 40 cycles at $95^{\circ} \mathrm{C}$ for $20 \mathrm{~s}, 58.3^{\circ} \mathrm{C}$ for $30 \mathrm{~s}$, and $68^{\circ} \mathrm{C}$ for $40 \mathrm{~s}$, and then heated to $95^{\circ} \mathrm{C}$ at a rate of $0.1^{\circ} \mathrm{C} / \mathrm{s}$. Fluorescence intensity was measured at the end of the elongation phase of each cycle. Melting curve analysis was then performed to confirm specific amplification of a single product by incrementally increasing the temperature at a rate of $0.5^{\circ} \mathrm{C} / \mathrm{s}$ from 65 to $95^{\circ} \mathrm{C}$. PCR product sizes were confirmed on a $1.5 \%$ agarose gel.

A standard curve was prepared using serial cDNA dilutions (from $2.36 \times 10^{9}-2.36$ x $\left.10^{5}\right)$ and plotted against the threshold cycle $\left(\mathrm{C}_{\mathrm{T}}\right)$, which denotes the cycles at which the fluorescence of the sample rises above background levels, with the slope of the standard curve indicating primer efficiency. The absolute amount of IBV RNA samples was calculated based on the standard curve. 


\section{Quantitative detection of IBV copies in the supernatant of CEK culture by real-time PCR}

To study the dynamics of IBV load in the supernatant of CEK cells post-infection, CEK cells were prepared, and the 20,54, and 87th generations of IBV-Sczy 3 at a $1000 \mathrm{X}$ dilution were chosen to infect CEK cells at 70-80\% confluency. Supernatant samples collected at $12,24,36,48,60$, and $72 \mathrm{~h}$ post-infection were detected by real-time RT-PCR. IBV copies fluctuating in the supernatant of CEK cells post-infection were determined using the equation:

$$
\log \mathrm{X}_{0}=\left(\mathrm{C}_{\mathrm{T}}-\mathrm{b}\right) / \mathrm{m}
$$

(Equation 2)

where $X_{0}$ represents the original copy number, $C_{\mathrm{T}}$ represent the cycle numbers when reaching the threshold, $b$ represents the intercept, and $m$ represents the slope. The copy numbers of IBV were calculated using the Bio-Rad IQ5 software.

\section{RESULTS}

\section{Passage of IBV Sczy3 strain in CEK cells and its cytopathic effect}

The allantoic fluids containing the IBV Sczy3 strain were used to infect CEK cells, and the supernatant of CEK cells was harvested $40 \mathrm{~h}$ post-inoculation and passaged blindly. The characteristic syncytia was observed beginning at $12 \mathrm{~h}$ post-infection in the 10-40th generations of IBV, and the number of syncytia increased gradually over time (Figure 1A and B); normal CEK cells were used as controls (Figure 1C). The plaque was observed beginning at 60 $\mathrm{h}$ post-infection. With increasing passaging, syncytia and plaque formation occurred earlier. The syncytia was observed at approximately $10 \mathrm{~h}$ post-infection in the 50-70th generations of the Sczy3 strain (Figure 1D), and the plaque was observed 36-48 h post-infection in the 80100th generations of the IBV Sczy3 strain (Figure 1E).

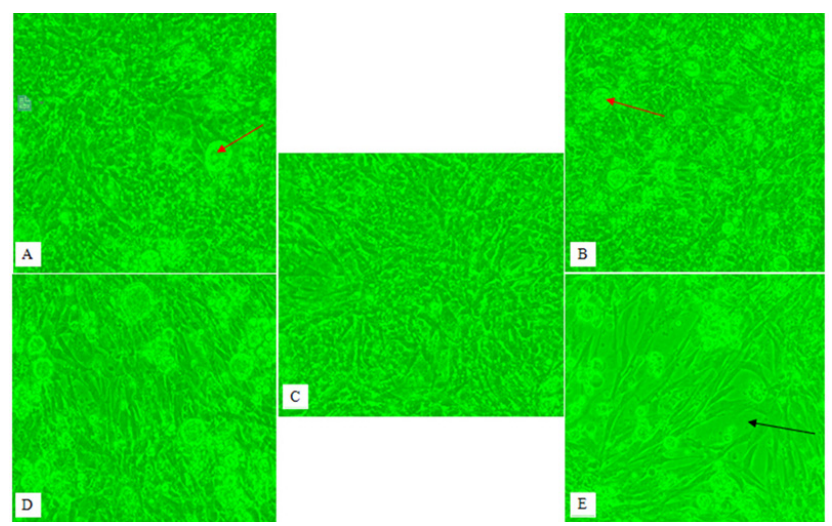

Figure 1. CPE on CEK cells and normal CEK cells. A. syncytiain CEK at $24 \mathrm{~h}$ post-infection of 40th generation of IBV Sczy3 strain; B. syncytia in CEK at 36 h post-infection of 40th generation of IBV Sczy3 strain; C. normal CEK cells were maintained as control (A. 100X); D. Syncytiain CEK at $24 \mathrm{~h}$ post-infection of 90th generation of IBV Sczy3 strain; E. plagues in CEK at $36 \mathrm{~h}$ post-infection of 90th generation of IBV Sczy3 strain. 


\section{Development of SYBR Green I-based real-time RT-PCR assay for IBV}

Standard curves for absolute quantification of IBV were generated. The detection and quantification limits were determined using $\mathrm{C}_{\mathrm{T}}$ values obtained for each reaction containing from $2.36 \times 10^{9}-2.36 \times 10^{5}$ copies $/ \mu \mathrm{L}$ of the standard plasmid. The values were plotted against the $\log$ of the number of template copies, and a linear equation:

$$
y=-3.393 x+41.956
$$

(Equation 3)

with a $\mathrm{R}^{2}$ value $=0.996$ was generated (Figure 2 ). The assay maintained linearity for at least 5 orders of magnitude and, using the slope from the linear equation, the overall efficiency of the assay was estimated to be $97.1 \%$.

The sensitivity of real-time RT-PCR was compared with that of conventional RT-PCR. The detection limit of real-time PCR was determined to be 10 template copies, while that of the conventional RT-PCR was $10^{3}$ template copies. (Figure 3). According to dilution analysis, real-time PCR was 100-fold more sensitive than conventional RT-PCR. The plasmid pMN$\mathrm{T}$ was diluted serially from $2.36 \times 10^{9}-2.36 \times 10^{5}$ copies $/ \mu \mathrm{L}$ and detected by real-time PCR assay for reproducibility (Figure 4). The results showed that the variation between duplicate determinations was low and the assay was linear with respect to $\mathrm{C}_{\mathrm{T}}$ value. The coefficient of variation $(\mathrm{CV})$ for the assay crossing points $\left(\mathrm{C}_{\mathrm{T}}\right.$ values $)$ for the different concentrations of IBV genomic cDNA are shown in Table 1 , and there was no significant difference $(\mathrm{P}>0.05)$ between mean $\mathrm{C}_{\mathrm{T}}$ values and mean plasmid copy number of 3 independent assays. The mean intra-assay $\mathrm{CV}$ based on the $\mathrm{C}_{\mathrm{T}}$ value was $0.2-0.8 \%$ and the mean inter-assay $\mathrm{CV}$ based on the $\mathrm{C}_{\mathrm{T}}$ value was $1.5-3.7 \%$.

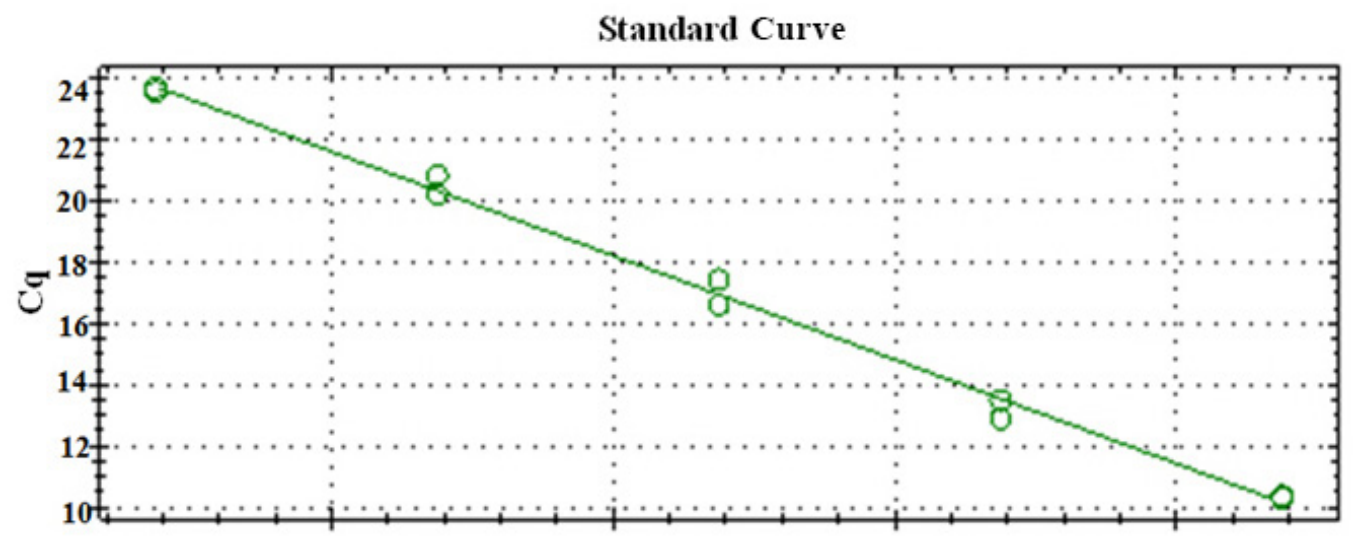

\section{Log Starting Quantity}

Figure 2. The standard curve was generated by plotting the $\mathrm{C}_{\mathrm{T}}$ values $v s \log _{10}$ of 10 -fold serial dilutions $(2.36 \mathrm{x}$ $10^{9}-2.36 \times 10^{5}$ ) of standard plasmid. An overall reaction efficiency of $97.1 \%$ was estimated using the standard curve slope as indicated by the formula. 


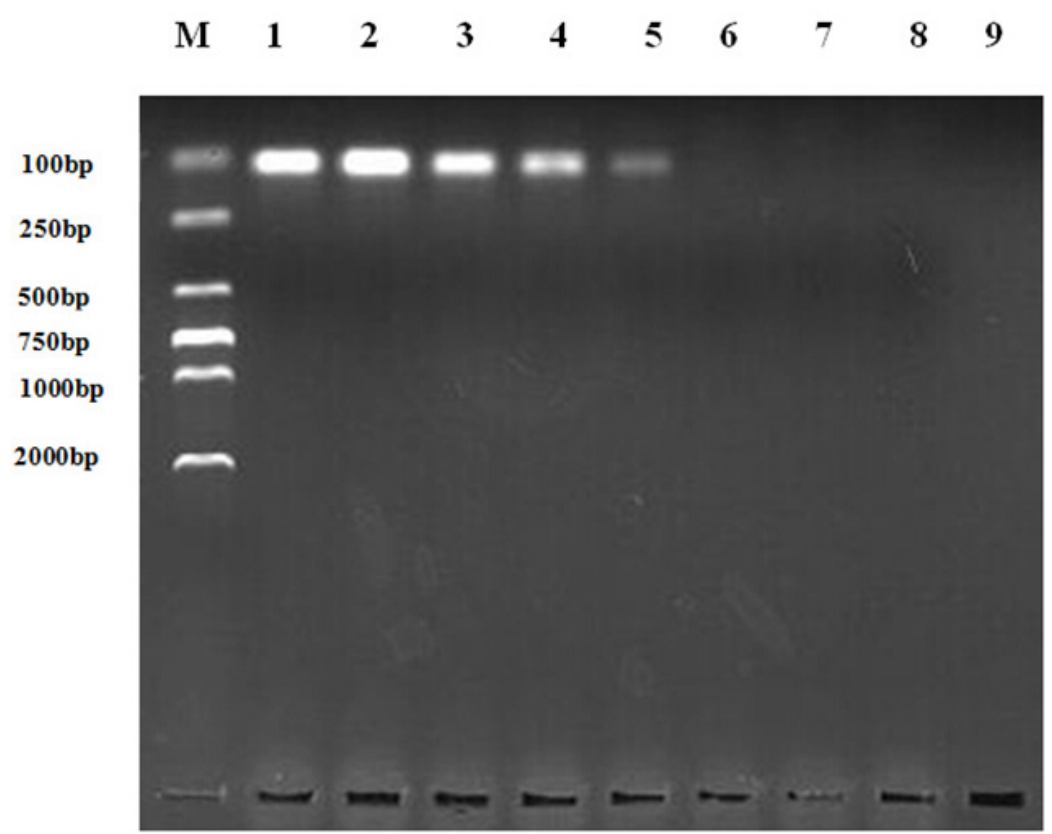

Figure 3. Sensitivity test of the amplification of common PCR. Lane $M=$ DL2000 maker; lanes 1-8= mixture template diluted $2.36 \times 10^{7}-2.36 \times 10^{0}$ copies $/ \mu \mathrm{L}$, respectively; lane $9=$ negative control.

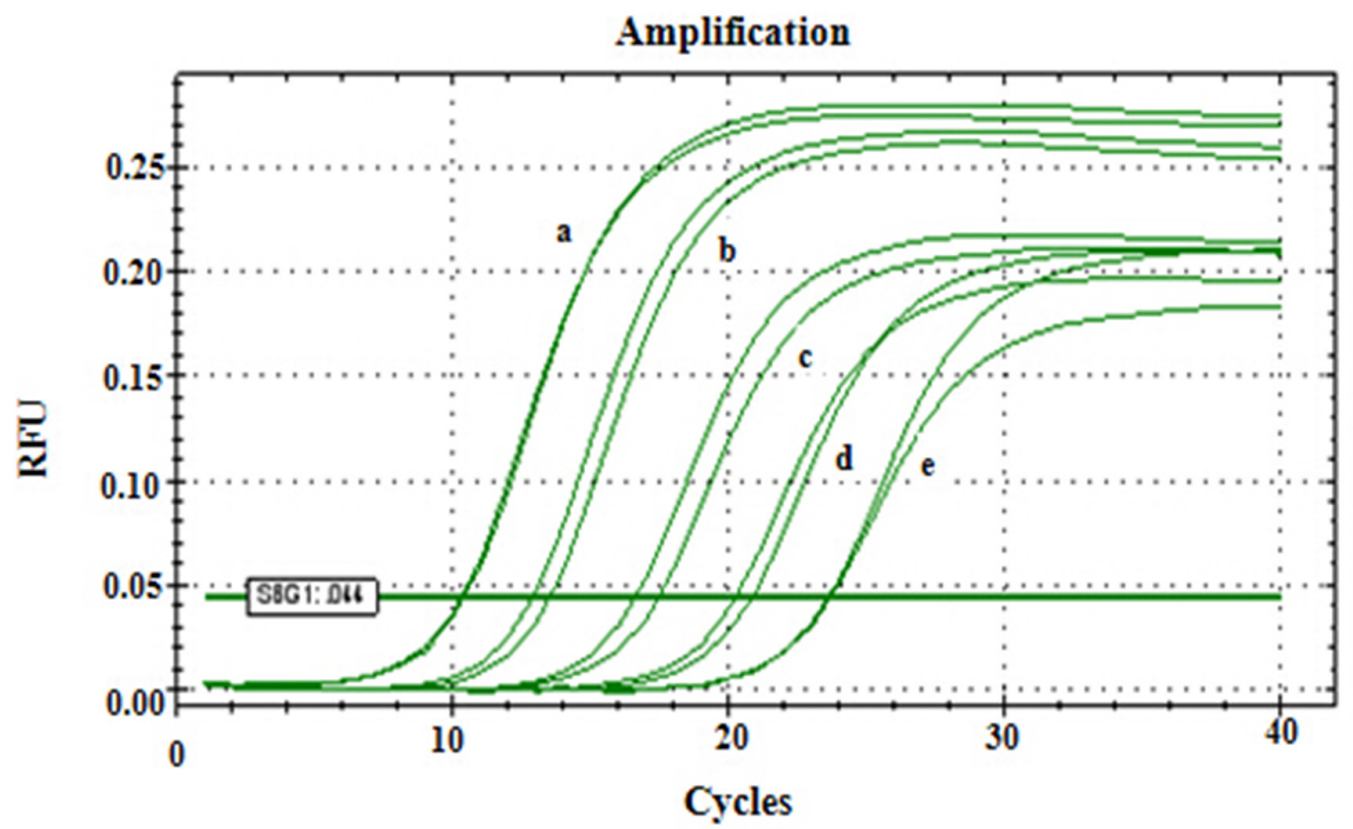

Figure 4. Reproducibility test of the SYBR Green I real-time PCR assay. Each plot corresponds to a particular input target copy number ranging from $2.36 \times 10^{9}-2.36 \times 10^{5}$ (a-e). RFU refers to relative fluorescence units. 
Table 1. Reproducibility of inter- and intra-assay by SYBR Green I real-time PCR.

\begin{tabular}{|c|c|c|c|c|c|c|c|c|c|c|}
\hline \multirow[t]{2}{*}{ Concentration of standard plasmid (copies $/ \mu \mathrm{L}$ ) } & \multicolumn{5}{|c|}{ Inter-assay Ct Value } & \multicolumn{5}{|c|}{ Intra-assay Ct Value } \\
\hline & 1 & 2 & 3 & $\operatorname{Avg} \mathrm{C}_{\mathrm{T}}^{\mathrm{a}}$ & $\mathrm{CV}^{\mathrm{b}}(\%)$ & 1 & 2 & 3 & $\operatorname{Avg} C_{T}$ & $\mathrm{CV}(\%)$ \\
\hline $2.36 \times 10^{9}$ & 14.6 & 15.26 & 16 & 15.3 & $3.7^{*}$ & 14.6 & 14.7 & 14.51 & 14.62 & 0.6 \\
\hline $2.36 \times 10^{8}$ & 17.8 & 18.6 & 19.5 & 18.63 & 3.6 & 18.2 & 18.3 & 18.21 & 18.26 & 0.3 \\
\hline $2.36 \times 10^{7}$ & 21.7 & 22.37 & 22.9 & 22.33 & 2.1 & 22.3 & 22.4 & 22.03 & 22.25 & 0.7 \\
\hline $2.36 \times 10^{6}$ & 26 & 25.69 & 25.1 & 25.59 & 1.5 & 24.6 & 24.7 & 24.64 & 24.65 & 0.2 \\
\hline $2.36 \times 10^{5}$ & 29.3 & 28.46 & 28.3 & 28.68 & 1.5 & 28.9 & 28.7 & 28.31 & 28.61 & $0.8 *$ \\
\hline
\end{tabular}

${ }^{a} \mathrm{Avg} \mathrm{C}_{\mathrm{T}}$ : average variance in $\mathrm{C}_{\mathrm{T}}$ value; ${ }^{\mathrm{b}} \mathrm{CV}$ : coefficient of variation, $\mathrm{CV}$ values less than $5 \%$ indicate good repeatability; *maximum variation coefficient.

\section{Dynamics of IBV loading in supernatant of CEK cells after IBV infection}

CEK cells were infected with the 1000 -fold dilution of the 20,54 , and 87 th generation of IBV-Sczy3, respectively. The samples of supernatant collected at 12, 24, 36, 48, 60, and $72 \mathrm{~h}$ post-infection were detected by real-time RT-PCR. The test results of the 6 different time points post-infection of the 3 different generations of Sczy3 were the follows: 1) The 20th generation values were: $4.63 \times 10^{6}, 2.65 \times 10^{9}, 2.89 \times 10^{9}, 8.36 \times 10^{8}, 3.66 \times 10^{8}$, and $2.64 \times 10^{8}$ copies, respectively; 2) The 54th generation values were: $3.83 \times 10^{7}, 1.65 \times 10^{9}, 1.93 \times 10^{9}, 1.12 \times 10^{9}$, $3.21 \times 10^{8}$, and $2.87 \times 10^{8}$ copies; 3) The 87 th generation values were: $5.07 \times 10^{7}, 7.59 \times 10^{7}$, $4.3 \times 10^{8}, 3.6 \times 10^{8}, 2.3 \times 10^{8}$, and $1.94 \times 10^{8}$ copies, respectively. The proliferation curve of the 3 different generations of IBV-Sczy3 in CEK cells all showed a single peak, and the time when IBV proliferation was most efficient was $12-36 \mathrm{~h}$ post-infection. The IBV load reached peaks at $36 \mathrm{~h}$ post-infection, and but then the load decreased gradually, and the peak of virus load among these 3 generations of CEK-adapted strains was 20th $>54$ th $>87$ th (Figure 5).

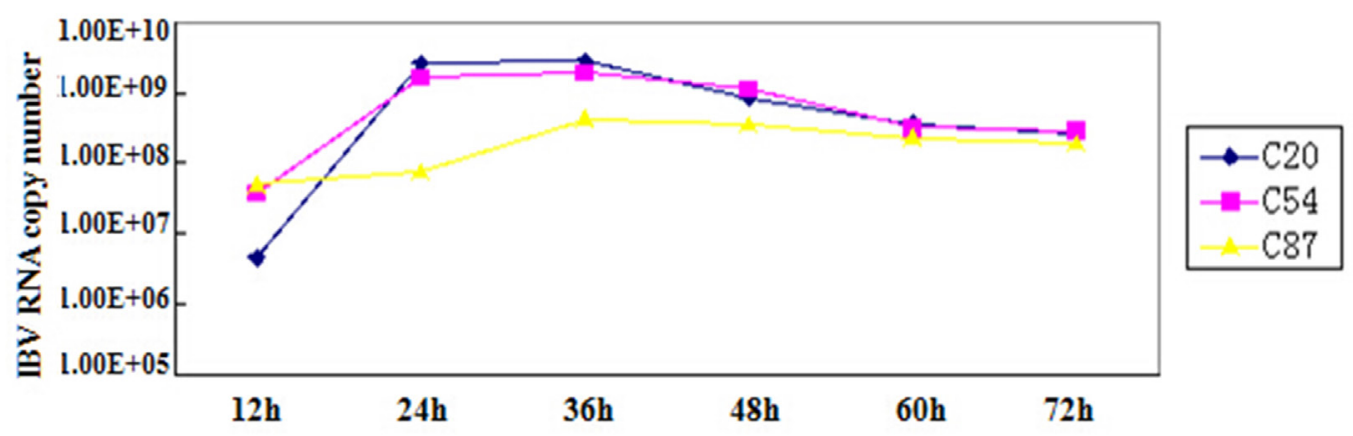

Time post infection (h)

Figure 5. Curve of virus replication in CEK cells infected with IBV-Sczy3.

\section{DISCUSSION}

IB occurs frequently in vaccinated and non-vaccinated flocks and causes severe economic losses in China. The disease is difficult to control because IBVs of different serotypes can provide partial cross-protection for each other; additionally, specific medications are not available. Currently, IB is controlled primarily by the use of vaccines such 
as H120, H52, Ma5, W93, and 4/91, among others, and filed strains the serotype differing from vaccine strains are frequently isolated (Cavanagh et al., 2002; Liu et al., 2006). Therefore, the development of new vaccines against IB is urgent. Currently, live attenuated vaccines are mainly prepared by chicken embryo proliferation, and vaccines prepared by cell culture have not been reported. IBVs can proliferate on CEK cells after adapting to chicken embryos, and attenuation of IBVs by CEK passaging have not been reported, but may provide new approach for controlling IB.

Real-time RT-PCR can be used for both fast and accurate quantification of viral load. To investigate the dynamic change in IBV-Sczy3 load in the supernatant of primary CEK cells, we developed and evaluated a SYBR Green I-based real-time RT-PCR assay for detecting and quantifying IBV directly from the culture supernatant of CEK cells. The target region for the assay was the nucleocapsid protein gene of IBV, which is highly conserved in most IBV strains. In this study, measures for mean inter- and intra-assay variation were similar, ranging from $0.2-0.8$ and $1.5-3.7 \%$, respectively, and the reproducibility of all assays with regards to the $\mathrm{C}_{\mathrm{T}}$ value appeared to be very good. The developed SYBR Green I-based real-time RT-PCR was 100 -fold more sensitive than conventional RT-PCR, showing a detection limit of 23.6 copies. This method was also more sensitive than real-time RTPCR as reported by Callison et al. (2005). The specificity and sensitivity of the assay can be evaluated by analyzing the melting curve (Callison et al., 2006; Liu and Liu, 2008). In addition, the assay was specific to IBV and did not detect any other tested avian pathogens. In conclusion, the method for quantifying IBV cDNA developed in this study was sensitive, specific, and time efficient.

In our study, the IBV-Sczy3 strain was propagated cultured and passaged serially in CEK cells. Dynamic changes in viral cDNA and the cytopathogenic effect were detected. The supernatant of CEK cells infected by the 20,54, and 87th generations of Sczy3 strains collected at $12,24,36,48,60$, and $72 \mathrm{~h}$ post-infection were detected. The result showed the most efficient time of IBV proliferation was $12-36 \mathrm{~h}$ post-infection. The IBV load reached peaks at $36 \mathrm{~h}$ post-infection, and then the load decreased gradually, which is consistent with the results of previous studies ( $\mathrm{Li}$ et al., 2011). Additionally, the peak of virus load among these 3 generations of CEK-adapted strains was 20th $>54$ th $>87$ th. The proliferation curve of these 3 generations of the Sczy 3 strain showed a single peak, and which of the 54th generation of Sczy3 was more typical and representative than these of the other 2 generations. This phenomenon may be related to the different adaptation in different generations of Sczy3 on CEK cells. With increased passage time, the Sczy3 strains became more adaptive on CEK cells. As CPE occurred earlier, CPE became more apparent. CPE is often related to cell death, which may block the proliferation of IBVs. Earlier CPE occurrence was association with a lower proliferation peak, resulting in lower total output of viral proliferation.

In conclusion, the real-time SYBR Green I-based PCR assay developed and validated in this study was highly sensitive and specific. It could be used for absolute quantitation of the viral cDNA of IBVs from the culture supernatant of CEK cells. The proliferative pattern of CEK-adapted IBVs in CEK cells and its cytopathogenic effect were also determined. This study may provide references for research on the adaptation of IBVs in cells and development of cell-adapted IBV vaccines. 


\section{ACKNOWLEDGMENTS}

Research supported by program for Changjiang Scholars and Innovative Research Team in University "PCSIRT" (Grant \#IRTO848). We thank all the people who contributed to the laboratory work.

\section{REFERENCES}

Bustin SA (2002). Quantification of mRNA using real-time reverse transcription PCR (RT-PCR): trends and problem. $J$. Mol. Endocrinol. 29: 23-39.

Callison SA, Hilt DA and Jackwood MW (2005). Rapid differentiation of avian infectious bronchitis virus isolates by sample to residual ratio quantitation using real-time reverse transcriptase-polymerase chain reaction. J. Virol. Methods 124: 183-190.

Callison SA, Hilt DA, Boynton TO, Sample BF, et al. (2006). Development and evaluation of a real-time Taqman RT-PCR assay for the detection of infectious bronchitis virus from infected chickens. J. Virol. Methods 138: 60-65.

Cavanagh D and Naqi SA (2003). Infectious Bronchitis. In: Diseases of Poultry (Saif YM, eds), Iowa State University Press, Ames, IA, pp. 101-119.

Cavanagh D, Mawditt K and Welchman DB (2002). Coronaviruses from pheasants (Phasianus colchicus) are genetically closely related to coronaviruses of domestic fowl (infectious bronchitis virus) and turkeys. Avian Pathology. 31: 81-93.

Cofia MF and Peterson JK (1971). Adaptation and propagation of avian infectious bronchitis virus in embryonic turkey kidney cell cultures. Avian Dis. 15: 22-27.

De Wit JJ, Mekkes DR, Kouwenhoven B and Verheijden JHM (1997). Sensitivity and specificity of serological tests for detection of infection bronchitis virus induced antibodies in broilers. Avain Pathol. 26: 105-118.

Gillette KG (1973). Plaque formation by infectious bronchitis virus in chicken embryo kidney cell cultures. Avian Dis. 17: 369-378.

Li HW, Wu JF, Zhuang YH, Gao F, et al. (2011). On propagation and adaptability of avian infectious bronchitis virus-M41 in chicken embryo kidney cells. J. Beijing Univ. Agric. 26: 31-34.

Liu FA (1983). Some observation on the adaption of the avian infectious bronchitis virus (IBV) to produce cytopathic effect (CPE) in chicken embryo kidney (CEK) cells. J. South China Agrucul. Coll. 4: 104-107.

Liu QR and Liu SW (2008). Development of a real-time PCR assay for detection of infectious bronchitis virus. Chin. J. Prev. Vet. Med. 30: 637-641.

Liu S, Zhang Q, Chen J, Han Z, et al. (2006). Genetic diversity of avian infectious bronchitis coronavirus strains isolated in China between 1995 and 2004. Archives of Virology. 151: 1133-1148.

Lukert PD (1965). Comparative sensitivities of embryonating chicken's eggs and primary chicken embryo kidney and liver cell cultures to infectious bronchitis virus. Avian Dis. 9: 308-316.

Lukert PD (1966). Immunofluorescence of avian infectious bronchitis virus in primary chicken embryo kidney, liver, lung, and fibroblast cell cultures. Avian Dis. 9:264-272.

Tan B, Wang HN and Shang LQ (2009). Coadministration of chicken GM-CSF with a DNA vaccine expressing infectious bronchitis virus (IBV) S1 glycoprotein enhances the specific immune response and protects against IBV infection. Arch. Virol. 154: 1117-1124.

Tripathy DN (1998). Infectious laryngotracheitis, A Laboratory Manual for the Isolation and Identification of Avian pathogens. In: American Association of Avian Pathologists (Swayne DE, Glisson JR, Jackwood MW, Pearson JE, Reed WM, eds.). Kennett Square, PA Press, Kennett, pp. 111-115.

Zou NL, Zhao FF, Wang YP, Liu P, et al. (2010). Genetic analysis revealed LX4 genotype strains of avian infectious bronchitis virus became predominant in recent years in Sichuan area, China. Virus Genes 41: 202-209. 